\begin{tabular}{lc}
\hline \hline UAD & Jurnal Psikologi Terapan dan Pendidikan \\
Vol. 2, No. 1, Mei 2020, pp.31-40 \\
ISSN $2715-2456$
\end{tabular}

\title{
Motivasi berprestasi pada siswa SMA dalam perspektif Islam
}

\author{
Budi Lenggono ${ }^{a, 1}$, Yuzarion ${ }^{b, 2 *}$
}

aSMA Islam Terpadu Nur Hidayah, Sukoharjo

bMagister Psikologi, Universitas Ahmad Dahlan, Yogyakarta

1budile_bio@yahoo.com; *2yuzarion@psy.uad.co.id

*Correspondent Author

\section{KATAKUNCI}

motivasi;

berprestasi;

perspektif Islam
KEYWORDS

achievement;

motivation;

Islamic perspective
ABSTRAK

Siswa SMA adalah kalangan remaja yang mendapat tuntutan sekaligus tantangan di dunia pendidikan untuk mencapai prestasi. Selain itu, siswa SMA memiliki kontribusi dalam peningkatan kualitas SDM di usia produktif. Studi literatur ini bertujuan untuk mengetahui bagaimana perspektif Islam mengenai motivasi berprestasi pada siswa SMA. Metode pada penelitian ini menggunakan studi literatur, yaitu berupa penelaahan empat belas jurnal utama dan beberapa literatur pelengkap terkait motivasi berprestasi dalam perspektif Islam. Hasil studi literatur meyimpulkan bahwa siswa SMA memerlukan motivasi berprestasi, dan dalam perspektif psikologi Islam motivasi berprestasi seiring dengan keimanan dan ketakwaan. Kesimpulan dari penelitian ini menunjukan bahwa semakin tinggi keimanan dan ketakwaan yang dimiliki siswa SMA, maka akan semakin tinggi pula motivasi berprestasi yang dimilikinya.

\section{Achievement motivation in high school students in Islamic perspective}

High school students are teenagers who have both demands and challenges in the world of education to achieve achievement. In addition, high school students have contributed to improving the quality of human resources at productive age. This literature study aims to find out how the Islamic perspective on achievement motivation in high school students. The method in this research uses literature study, which is in the form of reviewing fourteen main journals and some complementary literature related to achievement motivation in an Islamic perspective. The results of the literature study show that high school students need achievement motivation, and in the perspective of Islamic psychology, achievement motivation is in line with faith and piety. The conclusion of this study shows that the higher the faith and piety of high school students, the higher the achievement motivation they have.

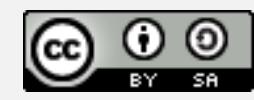

\section{Pendahuluan}

Pendidikan memiliki peranan yang sangat penting dalam pembangunan sumberdaya manusia Indonesia. Agar pendidikan dapat mencapai tujuan yang diharapkan, tentu 
diperlukan suatu kurikulum yang dapat beradaptasi dengan perkembangan dan tantangan zaman. Sebagaimana kurikulum yang paling mutakhir, yaitu kurikulum 2013 terdapat faktor tantangan internal dan eksternal yang harus dihadapi (Kemendikbud RI, 2013). Tantangan internal tersebut berupa jumlah penduduk Indonesia usia produktif (15-64 tahun) lebih banyak daripada usia tidak produktif (anak-anak berusia 0-14 tahun dan orang tua berusia 65 tahun ke atas). Kondisi ini mestinya mendorong pemerintah dan masyarakat untuk memberi perhatian pada sumberdaya manusia (SDM) usia produktif yang melimpah tersebut. Salah satu upaya yang dapat dilakukan pemerintah adalah dengan meningkatkan kualitas SDM agar memiliki kompetensi dan keterampilan.

Sementara itu, tantangan eksternalnya antara lain terkait dengan arus globalisasi, dan isu lingkungan hidup, kemajuan teknologi dan informasi, kebangkitan industri kreatif dan budaya, serta perkembangan pendidikan di tingkat internasional (Kemendikbud RI, 2018). Sehubungan dengan hal tersebut, pendidikan tingkat menengah atas (SMA dan sederajat) menjadi jalan yang paling memungkinkan untuk mengakselerasi peningkatan kualitas SDM pada permulaan usia produktif, dalam hal ini siswa SMA. Tentunya, kualitas siswa SMA perlu senantiasa dipantau dan diukur sehingga menjadi bahan evaluasi dari satuan pendidikan hingga ke level pengambil kebijakan. Pada gilirannya prestasi belajar menjadi patokan untuk menentukan apakah siswa SMA mampu memenuhi kualitas atau kriteria SDM yang diharapkan.

Prestasi belajar dalam skala nasional dapat dilihat pada hasil ujian nasional yang diselenggarakan oleh pemerintah. Berdasarkan data hasil ujian nasional dalam empat tahun terakhir (2016-2019), prestasi belajar siswa SMA masih menunjukkan hasil yang kurang memuaskan (Kemendikbud RI, Puspendik, 2019). Hasil ujian nasional yang masih sangat rendah tersebut tentu menjadi permasalahan pendidikan yang patut diperhatikan oleh semua pihak. Hal ini mendorong setiap sekolah untuk mencetak peserta didik yang berkualitas dan mencapai prestasi belajar yang diharapkan.

Di lain pihak, abad ke-21 adalah abad akselerasi dalam berbagai aspek termasuk pendidikan. Remaja yang duduk di bangku sekolah menengah atas (SMA) atau sederajat menjadi bagian dari entitas pendidikan tersebut yang kini dituntut untuk memiliki prestasi yang kompetitif di era global. Siswa SMA yang memiliki prestasi yang relatif rendah akan tersingkir dalam kancah kompetisi regional terlebih global. Oleh karena itu, motivasi teramat penting bagi siswa SMA untuk meraih prestasi agar mampu memasuki jenjang pendidikan yang lebih tinggi yang pada gilirannya memperoleh pekerjaan yang lebih layak.

Fenomena rendahnya motivasi berprestasi pada siswa SMA telah memberikan dampak pengaruh pada kemunduran prestasi belajar (Utomo, Atmoko, \& Hitipeuw, 2018). Padahal, guru telah merancang kegiatan pembelajaran, tetapi pada kemyataannya masih banyak siswa yang memiliki motivasi berprestasi yang rendah (Savitri, Santyasa, \& Rapi, 2017). Sementara itu, perpustakaan yang harapannya menjadi tempat menambah ilmu, jauh lebih sepi daripada gedung bioskop, mall dan kafe yang merupakan tempat hiburan dan tempat nongkrong (Fakhria \& Setiowati, 2017). Namun demikian, sebenarnya orientasi pencapaian siswa tidak semata-mata dipengaruhi oleh guru tetapi dibentuk oleh iklim kelas secara keseluruhan, termasuk posisi sosial siswa di kelas (Poledňová, Stránská, \& Niedobová, 2014).

Sebagai bagian dari perilaku siswa dalam konteks belajar, motivasi berprestasi dalam belajar memainkan peran yang sama seperti halnya faktor-faktor lain yang mempengaruhi prestasi belajar siswa pada umumnya. Di sisi lain, siswa SMA sebagai golongan remaja yang diasumsikan telah aqil baligh dalam konteks Islam tentu memiliki kekhasan tersendiri berkaitan dengan motivasi berprestasi. Namun, tidak banyak penelitian yang dilakukan dalam hal motivasi berprestasi terutama pada siswa SMA, termasuk kajiannya dalam perspektif Islam.

Motivasi berprestasi adalah usaha seseorang untuk mencapai keberhasilan dalam suatu kompetisi yang termasuk dalam suatu standar keunggulan yang mana motivasi akan muncul ketika individu berinteraksi dengan orang lain maupun lingkungannya (McClelland, 1987). 
Gage dan Berliner (1984) juga menjelaskan bahwa motivasi berkaitan dengan situasi yang menggugah (aurosed) atau dikenal dengan situasi aurosal dan mengarah ke tujuan tertentu. Kaitannya dengan dunia akademik, Tucker, Zayco, dan Herman (2002) menyatakan bahwa motivasi berprestasi merupakan keterlibatan akademik individu yang mengacu pada indikator kognitif, emosional, dan usaha investasi diri untuk mencapai prestasi akademik. Singh (2011) menambahkan bahwa motivasi berprestasi merupakan kebutuhan untuk melakukan dengan baik atau berjuang untuk sukses yang dibuktikan dengan ketekunan dan usaha dalam mengadapi kesulitan.

Adapun Awan, Noureen, dan Naz (2011) mengartikan motivasi berprestasi sebagai kemampuan individu untuk mencapai kebutuhan mereka dengan berusaha mencapai penghargaan, kepuasan fisik, pujian dari orang lain, dan perasaan penguasaan pribadi. Berdasarkan pengertian-pengertian tersebut disimpulkan bahwa motivasi berprestasi adalah usaha individu yang dilakukan dengan tekun untuk menggapai keberhasilan yang dipicu oleh interaksi dirinya dengan orang lain atau lingkungannya sehingga kebutuhannya terpenuhi.

Penelitian ini bertujuan untuk melakukan kajian tentang perspektif Islam dalam motivasi berprestasi di kalangan siswa SMA. Studi pustaka motivasi berprestasi siswa SMA dalam perspektif Islam ini penting karena tiga alasan. Pertama, masih sedikit penelitian tentang perspektif Islam dalam motivasi berprestasi siswa SMA. Diharapkan hasil studi pustaka ini nantinya dapat memberikan informasi atau gagasan mengenai tema penelitian untuk analisis kualitatif atau kuantitatif lebih lanjut. Kedua, prestasi belajar siswa SMA skala nasional memiliki capaian yang rendah yaitu rerata empat tahun terakhir hanya sebesar 51,26 dan tergolong capaian yang rendah (Kemendikbud RI, Puspendik, 2019). Capaian ini mendorong berbagai pihak untuk berupaya meningkatkan prestasi belajar siswa, salah satunya dengan meningkatkan perhatian pada motivasi berprestasi mereka. Ketiga, motivasi berprestasi siswa SMA merupakan bagian dari upaya untuk menunjang peningkatan kualitas SDM Indonesia pada usia produktif yang perlu dipersiapkan sebaik-baiknya.

\section{Metode}

Penelitian ini merupakan penelitian studi literatur dengan menelaah beberapa jurnal dan literatur pelengkap terkait motivasi berprestasi. Hasil dari berbagai telaah literatur ini akan digunakan untuk mengetahui bagaimana perspektif Islam mengenai motivasi berprestasi pada siswa SMA. Kriteria inklusi dilakukan dengan memetakan artikel jurnal dengan kriteria sebagai berikut: 1) mempelajari tentang motivasi dan motivasi berprestasi, terutama dalam perspektif Islam; 2) penelitian yang dilakukan berhubungan dengan dunia remaja Islam. Kriteria eksklusi dilakukan dengan kriteria sebagai berikut: 1) artikel jurnal menggunakan bahasa Indonesia atau bahasa Inggris; 2) dapat sepenuhnya diunduh; 3) berupa penelitian, tinjauan pustaka atau hasil pengamatan. Proses analisis pada hasil penelitian pada dasarnya dilakukan dengan mengidentifikasi topik penelitian, tahun publikasi, tujuan penelitian, metode penelitian, instrumen pengumpulan data, analisis data dan hasil penelitian untuk menentukan artikel jurnal yang ditinjau.

Kriteria inklusi dilakukan dengan memetakan artikel jurnal dengan kriteria sebagai berikut: 1) mempelajari tentang motivasi dan motivasi berprestasi, terutama dalam perspektif Islam; 2) penelitian yang dilakukan berhubungan dengan dunia remaja Islam. Kriteria eksklusi dilakukan dengan kriteria sebagai berikut: 1) artikel jurnal menggunakan bahasa Indonesia atau bahasa Inggris; 2) dapat sepenuhnya diunduh; 3) berupa penelitian, tinjauan pustaka atau hasil pengamatan. Proses analisis pada hasil penelitian pada dasarnya dilakukan dengan mengidentifikasi topik penelitian, tahun publikasi, tujuan penelitian, metode penelitian, instrumen pengumpulan data, analisis data dan hasil penelitian untuk menentukan artikel jurnal yang ditinjau. 


\section{Hasil dan Pembahasan}

Motivasi berasal dari kata motif yang berarti alasan seseorang untuk melakukan sesuatu (Salim \& Salim, 1991). Setiap orang melakukan sesuatu, memiliki tujuan tertentu yang telah diperhitungkan untung ruginya; tidak berhenti pada untung rugi, melainkan juga harus ada alasan baik buruk, halal haram dan sebagainya yang berhubungan erat dengan nilai dan tatanan norma Islam (Sapuri, 2009). Motivasi dan kebutuhan adalah dua kata yang saling berkaitan satu dengan lainnya. Terkadang motivasi digunakan sabagai kata yang bermakna kebutuhan dan juga sebaliknya. Motivasi adalah satu implikasi yang muncul karena suatu ketidakteraturan secara biologis ataupun psikologis dalam dirinya. Sementara yang disebut dengan kebutuhan adalah ruh ketidakberaturan atau kekurangan tersebut (Izzanuddin, 2006).

Gage dan Berliner (1984) menyatakan bahwa istilah motivasi berkaitan dengan situasi di mana seseorang menjadi tergugah (aroused) dan kemudian mengarahkan perilaku tersebut pada suatu tujuan tertentu. Seseorang yang memiliki motivasi berprestasi tinggi akan selalu bersemangat dan berambisi tinggi, melakukan tugas yang diberikan padanya dengan sebaik mungkin, belajar dengan lebih cepat, dan memiliki prestasi dalam bidang yang menjadi keahlian mereka (Santrock, 2011). Studi percobaan mengenai motivasi berprestasi bermula dari taksonomi Murray mengenai sistem kebutuhan dan dilanjutkan dengan pengembangan TAT (Thematic Apperception Test) untuk mengetahui gambaran motivasi seseorang.

TAT dikembangkan oleh Christina Morgan dan Henry Murray berdasarkan fakta bahwa ketika seseorang menginterpretasi situasi sosial yang ambigus, maka mereka akan menjawab dengan mengekspose kepribadiannya sendiri seperti manakala mereka menghadapi fenomena tersebut. Selanjutnya, Murray mendefinisikan $n$-ach sebagai kebutuhan untuk menyelesaikan sesuatu yang sulit, menguasai sesuatu dengan cepat dan mandiri, menyelesaikan permasalahan dan mencapai standar yang tinggi, menantang diri sendiri, bersaing dan mengungguli orang lain, mengembangkan penguasaan atas objek fisik, kemanusiaan, dan ide, serta melakukan semua hal tersebut sebagai kebanggaan, dengan latihan-latihan yang baik (Hall \& Lindsey, 1985). Hal tersebut erat kaitannya dengan dunia pendidikan, termasuk di jenjang SMA. Tidak sekedar sebagai jenjang pendidikan menengah, SMA merupakan jenjang transisi yang menentukan arah seseorang untuk menuju citacitanya. Seseorang dalam jenjang SMA ini, yaitu remaja, selain memiliki berbagai tuntutan kurikulum, juga dituntut harus siap dan mampu dalam menghadapi tantangan kehidupan dan pergaulan (Jannah, 2016).

Tuntutan kurikulum beserta tantangan kehidupan dan pergaulan dapat menjadi sebab seorang siswa SMA merasa tertantang dan memiliki kebutuhan untuk berprestasi di sekolah sehingga menunjukkan usaha dalam rangka mencapai tugas yang sulit sekalipun. McClelland (1987) menyatakan bahwa individu dengan kebutuhan berprestasi tinggi akan lebih memilih tugas-tugas dengan tingkat kesulitan moderat, karena tugas tersebut memiliki unsur menantang kemampuan dan masih dalam batas-batas kemampuan untuk dapat dikerjakan oleh seseorang. Sebaliknya individu yang memiliki $n$-ach lebih rendah memilih tugas dengan kesulitan tinggi atau rendah sekali. Hal ini terjadi karena mereka tidak menyukai situasi di mana adanya tantangan dan ancaman akan kemampuan mereka.

Perbedaan ini juga terlihat dalam strategi pemecahan masalah. Individu dengan $n$-ach tinggi memiliki strategi pemecahan masalah yang mendukung usahanya dalam mencapai hasil yang diinginkan. Sebaliknya inidvidu dengan $n$-ach rendah tidak memiliki strategi dalam pemecahan masalah, serta cenderung mudah putus asa dalam menghadapi kesulitan. McClelland (1987) juga menjelaskan bahwa motivasi berprestasi dipengaruhi oleh dua faktor yaitu faktor intrinsik dan faktor ekstrinsik. Faktor intrinsik meliputi kemungkinan untuk sukses, ketakutan akan kegagalan, value, self-efficcacy, usia, pengalaman dan jenis kelamin. Sementara faktor eksternal meliputi lingkungan sekolah, keluarga, dan teman.

Penelitian Suranto (2015) menunjukkan bahwa motivasi belajar berpengaruh positif dan signifikan terhadap prestasi belajar. Pengaruh positif menunjukkan bahwa semakin tinggi 
motivasi yang dimiliki siswa akan dapat meningkatkan prestasi belajar siswa tersebut. Sementara penelitian Haryani dan Tairas (2014), menunjukkan bahwa ada faktor intrinsik serta ekstrinsik yang berpengaruh terhadap motivasi berprestasi pada mahasiswa tidak mampu secara ekonomi. Faktor awal yang mempengaruhi adalah faktor eksternal, yaitu keluarga atau pihak sekolah. Melalui keberhasilan yang mereka peroleh setelah proses awal tersebut mulai muncul faktor intrinsik dalam diri mereka, yaitu kemungkinan untuk sukses yang ingin mereka raih selanjutnya. Seiring dengan pendidikan mereka yang lebih lanjut faktor sekolah, keluarga dan lingkungan (teman) memberikan pengaruh yang lebih besar. Terutama kondisi ekonomi keluarga mereka yang berasal dari keluarga tidak mampu secara ekonomi, membuat mereka ingin berhasil dan pada akhirnya mampu memperbaiki kondisi ekonomi keluarga. Faktor-faktor eksternal lain yang juga berpengaruh pada motivasi berprestasi mereka adalah pengalaman yang dimiliki serta orang lain yang lebih dulu sukses.

Adapun dalam penelitian Hendrati (2014), terhadap beberapa guru SD menunjukkan ada beberapa guru dengan masa kerja mengajar lebih dari 5 tahun semakin malas artinya sering datang terlambat, kurang inovatif dan kreatif dalam mengajar, kurang update dalam metode pembelajaran bahkan terkesan monoton, juga kurang berminat dalam mengajar. Hasil penelitian ini menstimulan peneliti untuk berasumsi bahwa rendahnya kinerja guru dikarenakan motivasi berprestasinya rendah, dimana guru menganggap bahwa berkualitas atau tidaknya proses yang dilakukan oleh mereka tidak akan mempengaruhi gaji yang mereka peroleh.

Siswa SMA memiliki rentang usia antara 15-19 tahun. Pada rentang usia ini, seseorang berada pada masa remaja (adolescent). Masa remaja adalah periode kritis sebagai peralihan dari tahap kanak-kanak menuju tahap dewasa. Pada masa remaja, seseorang mengalami perubahan hormonal, fisik, psikologis maupun sosial yang berlangsung secara sekuensial, kemudian mengalami apa yang disebut akil baligh. Baligh adalah anak yang sudah mencapai usia yang mengalihkannya dari masa kanak-kanak (thufulah) menuju masa kedewasaan (rujulah/unutsah) (Kartika, 2017). Umumnya, pada anak perempuan pubertas terjadi pada usia 8 tahun sedangkan anak laki-laki terjadi pada usia 9 tahun (Jannah, 2016). Hassan dan Abdullah (2018) menyatakan bahwa remaja merupakan golongan usia muda yang dapat memaksimalkan energi dan potensinya dalam mengambil peran di segala aspek kehidupan.

Remaja tanpa membedakan laki-laki maupun perempuan, keduanya terlibat dalam perilaku motivasi berprestasi pada konteks tantangan di level yang tidak berbeda. Penelitian Howard (2016), menunjukkan bahwa laki-laki dan perempuan tidak berbeda secara signifikan dalam pengalaman motivasi mereka. Namun demikian, setiap orang memiliki gaya motivasi yang berbeda dalam upaya fokus menghadapi tantangan. Hal ini senada dengan penelitian Cramer, Lafreniere, Ianni, dan Lafreniere (2015) yang menunjukkan bahwa fokus seseorang dikaitkan dengan respons yang lebih konsisten pada profil gaya motivasi.

Dalam menghadapi tantangan, remaja dapat mengalami goncangan sehingga melakukan perilaku negatif. Perilaku negatif dapat timbul dari berbagai masalah wajar sebelumnya yang semakin menguat. Ada tiga hal yang dapat menjadi penyebabnya, antara lain: 1) dirinya kurang mampu menyesuaikan diri dengan pertumbuhan dan perkembangannya serta tidak mampu menerima apa yang diraihnya; 2) adanya berbagai tekanan lingkungan, seperti dari orang tua dan teman sebaya serta masyarakat yang lebih luas; dan 3) tidak mampu menyesuaikan diri dengan berbagai tekanan yang ada (Al-Mighwar, 2011).

McClelland (1987) mengemukakan ada enam karakteristik individu yang mempunyai motivasi berprestasi yang tinggi. Pertama, perasaan yang kuat untuk mencapai tujuan, yaitu keinginan untuk menyelesaikan tugas dengan hasil yang sebaik-baiknya. Kedua, bertangungjawab, yaitu mampu bertanggungjawab terhadap dirinya sendiri dan menentukan masa depannya sehingga apa yang dicita-citakan berhasil tercapai. Ketiga, evaluatif, yaitu menggunakan umpan balik untuk menentukan tindakan yang lebih efektif guna mencapai prestasi, kegagalan yang dialami tidak membuatnya putus asa, melainkan sebagai pelajaran untuk berhasil. Keempat, mengambil risiko "sedang" dalam arti tindakan-tindakannya sesuai 
dengan batas kemampuan yang dimilikinya. Kelima, kreatif dan inovatif, yaitu mampu mencari peluang-peluang dan menggunakan kesempatan untuk dapat menunjukkan potensinya. Keenam, menyukai tantangan, yaitu senang akan kegiatan-kegiatan yang bersifat prestatif dan kompetitif.

Selanjutnya di dalam ajaran Islam, motivasi berkaitan erat dengan belajar yang salah satu tujuannya adalah untuk menguasai ilmu. Hal ini sesuai dengan hadis dari Abu Waqid AlHarits bin 'Auf Radhiyallahu 'Anhu yang menyatakan bahwa Rasulullah Shallallahu 'Alaihi wa sallam ketika sedang duduk di masjid dan orang-orang sedang bersamanya, tiba-tiba datanglah tiga orang. Maka dua orang menghampiri Rasulullah shallallahu 'alaihi wa sallam sedangkan yang satu pergi. Lalu, kedua orang tua itu berdiri di depan Rasulullah shallallahu 'alaihi wa sallam. Salah satunya melihat tempat yang kosong di perkumpulan tersebut, maka ia duduk di sana. Sedangkan yang satu lagi, duduk di belakang mereka. Adapun orang yang ketiga pergi. Maka ketika Rasulullah shallallahu 'alaihi wa sallam selesai, beliau berkata, "Maukah aku beritahukan kepada kalian tentang tiga orang? Yang pertama, ia berlindung kepada Allah, maka Allah pun melindunginya. Yang kedua, ia malu, maka Allah pun malu terhadapnya. Sedangkan yang ketiga, ia berpaling maka Allah pun berpaling darinya." (Muttafaqun 'alaih. HR. Bukhari, no. 66 dan Muslim, no. 2176)

Berdasarkan hadis tersebut dapat diambil hikmah bahwa menuntut ilmu dan memiliki motivasi dalam melakukannya merupakan hal yang penting untuk mendapat ridha Allah SWT. Nabi Muhammad SAW mampu memberikan motivasi kepada umatnya berkaitan dengan menuntut ilmu waulaupun tidak dipungkiri setiap orang memiliki kapasitas yang berbeda-beda ketika mereka sedang belajar. Motivasi anak didik untuk menerima pelajaran tentu berbeda-beda, ada anak didik yang memiliki motivasi sangat tinggi, sedang, bahkan ada anak didik yang tidak memiliki motivasi (Djamarah, 2010).

Menurut Gage dan Berliner (1984), ada enam faktor yang memengaruhi motivasi. Pertama, faktor minat individu yaitu semakin tinggi minat siswa terhadap yang dipelajari, maka ia akan semakin tekun mempelajarinya. Kedua, faktor kebutuhan individu, yaitu semakin individu merasa membutuhkan sesuatu yang sedang dipelajari, maka ia akan semakin tekun mempelajarinya. Ketiga, mempelajarinya. Keempat, faktor sikap individu, yaitu semakin positif sikap individu terhadap sesuatu yang sedang dipelajari, maka ia akan semakin senang mempelajarinya. Kelima, faktor aspirasi individu, yaitu semakin besar aspirasi individu untuk mencapai prestasi tinggi dalam bidang yang dipelajarinya sekarang maka ia akan semakin gigih dalam belajarnya. Terakhir, faktor insentif yaitu semakin tinggi insentif yang dirasakan oleh individu dari sesuatu yang dipelajarinya, maka ia akan semakin kuat mempelajarinya.

El-Fiky (2011), dalam bukunya menyebutkan bahwa ketika seseorang memiliki motivasi dan dorongan psikologi maka semangat akan lebih banyak, kemampuan akan lebih besar, dan pengetahuan akan lebih baik. Sebaliknya, jika semangat lemah maka individu tidak akan memiliki kemampuan, dan konsentrasi hanya tertuju pada hal-hal yang bersifat negatif. Oleh karena itu, pekerjaan tidak akan optimal. Terdapat tiga jenis motivasi menurut El-Fiky. (1) motivasi hidup, yaitu motivasi yang mendorong manusia untuk memenuhi kebutuhan primernya, misalnya makanan, air, dan udara. Jika kebutuhan primer kurang maka motivasi dasar di dalam diri individu yang mengingatkan saraf di otak tentang kekhususankekhususan yang akan mendorong seseorang untuk semangat berkerja demi memenuhi kekurangan ini. (2) Motivasi Eksternal, yaitu motivasi yang berasal dari eksternal seperti motivator ulung, atau teman-teman, anggota keluarga, majalah-majalah, buku, atau para pemimpin di kantor, namun motivasi tersebut lebih cepat hilang. (3) Motivasi Internal, di mana jenis motivasi ini paling kuat dan paling tahan lama. Motivasi internal yang dimiliki dapat mengendalikan kekuatan internal seseorang yang tentu saja akan menuntun dalam mewujudkan pencapaian-pencapaian besar.

Ajaran Islam memiliki perspektif terhadap motivasi berprestasi. Hal ini sebagaimana dinyatakan dalam ayat al-Qur'an,"Hai orang-orang beriman apabila dikatakan kepadamu: 
"Berlapang-lapanglah dalam majlis", maka lapangkanlah niscaya Allah akan memberi kelapangan untukmu. Dan apabila dikatakan: "Berdirilah kamu", maka berdirilah, niscaya Allah akan meninggikan orang-orang yang beriman di antaramu dan orang-orang yang diberi ilmu pengetahuan beberapa derajat. Dan Allah Maha Mengetahui apa yang kamu kerjakan." (Q.S. Al-Mujadilah: 11). Selain itu, disebutkan pula, "(Apakah kamu hai orang musyrik yang lebih beruntung) ataukah orang yang beribadat di waktu-waktu malam dengan sujud dan berdiri, sedang ia takut kepada (azab) akhirat dan mengharapkan rahmat Tuhannya? Katakanlah: 'Adakah sama orang-orang yang mengetahui dengan orang-orang yang tidak mengetahui?' Sesungguhnya orang yang berakallah yang dapat menerima pelajaran." (Q.S. AzZumar: 9).

Adapun dalam hadis Nabi Muhammad SAW disebutkan, "Menuntut ilmu wajib atas tiaptiap muslim laki-laki dan muslim perempuan” (HR. Ibnu Abdil Bari). Di hadis lain disebutkan, "Kelebihan orang yang berilmu dari orang yang beribadah (yang bodoh) bagaikan kelebihan bulan pada malam purnama dan semua bintang-bintang yang lain." (Diriwayatkan oleh Abu Dawud, At-Tirmidzi, An-Nasa"i, dan Ibnu Majah dari Abu Darda).

Kutipan ayat al-Qur'an dan hadist tersebut di atas memberikan pengertian bahwa timbulnya motivasi berasal dari tuntunan Sang Pencipta, yaitu Allah Subhanahu Wata'ala. Tuntunan tersebut dapat berupa perumpamaan-perumpamaan. Dengan demikian, umat Islam memperoleh pemahaman dari tuntunan Allah dan rasul-Nya kemudian tumbuh motivasinya dalam menuntut ilmu.

Selanjutnya, Allah SWT juga berfirman dalam Al-Quran, "Sesungguhnya Allah tidak mengubah keadaan suatu kaum sehingga mereka mengubah keadaan yang ada pada diri mereka sendiri" (Ar-Ra'd: 11). Berdasarkan ayat tersebut menunjukkan bahwa ternyata motivasi yang paling kuat berasal dari diri sendiri. Sementara itu, saat ini semakin banyak remaja mengalami hambatan dalam melaksanakan tugas perkembangannya padahal remaja dituntut agar mampu beradaptasi dengan perkembangan zaman dengan tetap menjaga keimanan yang kokoh (Jannah, 2016).

Motivasi merupakan dorongan yang sangat menentukan tingkah laku dan perbuatan manusia. Motivasi menjadi kunci utama dalam menafsirkan dan melahirkan perbuatan manusia. Peranan yang demikian menentukan ini, dalam konsep Islam disebut sebagai niyyah dan 'ibadah. Niyyah merupakan pendorong utama manusia untuk berbuat atau beramal. Sementara, 'ibadah adalah tujuan manusia berbuat atau beramal (Baharuddin, 2004).

Motivasi berprestasi dalam Islam menggambarkan niat dan upaya yang sungguhsungguh untuk menuntaskan sebuah pekerjaan. Sementara itu, hasilnya akan diperoleh sebanding dengan usaha yang dilakukannya. Balasan suatu pekerjaan tidak semata-mata berupa materi, tetapi juga berupa pahala dari Allah SWT. Bentuk dan besarnya apa yang diperoleh tersebut juga ada yang dapat dinikmati secara langsung, ada pula yang baru dapat dirasakan dalam waktu tunggu yang relatif lama. Hal ini senada dengan firman Allah SWT, "Berlomba-lombalah kamu kepada (mendapatkan) ampunan dari Tuhanmu dan surga yang luasnya seluas langit dan bumi, yang disediakan bagi orang-orang yang beriman kepada Allah dan Rasul-rasul-Nya. Itulah karunia Allah, diberikan-Nya kepada siapa yang dikehendaki-Nya. Dan Allah mempunyai karunia yang besar" (QS. Al Hadid (57): 21).

Syaikh Abdul 'Aziz bin Baazz Rahimahullau (Hakim, 2016) menyatakan bahwa pemuda di setiap umat adalah tulang punggung yang membentuk komponen pergerakan karena mereka memiliki kekuatan yang produktif dan kontribusi (peran) yang terus-menerus. Remaja dalam konteks sejarah Islam memiliki peran yang sangat penting dalam mencapai keberhasilan dakwah. Sebagai contoh, pemuda muslim dari kalangan sahabat yang mulia, seperti Ali bin Abi Thalib radhiyallahu 'anhu, rela tidur bertaruh nyawa di ranjang Nabi Muhammad shallallahu 'alaihi wa sallam ketika peristiwa hijrah orang-orang kafir berniat mengadakan makar bahkan pembunuhan. Ada pula Abdullah bin Abu Bakr Radhiyallahu 'Anhu, berperan sebagai mata-mata untuk mencari info tentang kondisi dan situasi masyarakat Quraisy yang memusuhi Islam untuk diberitakan kepada Nabi shallallahu 'alaihi 
wa sallam. Adapun Usamah bin Zaid Radhiyallahu 'Anhu yang merupakan sosok remaja yang bertugas memimpin pasukan yang di dalamnya terdapat para sahabat senior radhiyallahu 'anhum.

Para remaja pada peristiwa-peristiwa di atas menunjukkan bahwa mereka memiliki motivasi berprestasi untuk meraih suatu tujuan yang mulia. Pada konteks kekinian dan dunia sekolah, siswa SMA adalah entitas remaja yang memiliki peluang yang sama dalam konteks perjuangan dirinya untuk meraih cita-cita yang didambakan atau harapan orang tua mereka masing-masing. Bahkan lebih dari itu, seorang remaja menyimpan potensi untuk merealisasikan ide dan gagasannya karena sebuah dorongan atau motivasi yang kuat. Sebagaimana kisah Nabi Ibrahim 'alaihi salam dalam Al Qur'an, "Ingatlah ketika ia (Ibrahim) berkata kepada bapaknya: Wahai bapakku, mengapa kamu menyembah sesuatu yang tidak mendengar, tidak melihat, dan tidak dapat menolong sedikitpun?" (QS. Maryam: 42). Seorang Nabi Ibrahim 'alaihi salam muda tersebut begitu tegas dan berani mengutarakan apa yang diyakininya sebagai sesuatu yang benar karena dorongan motivasi berprestasi demi meraih tujuan yang mulia, yaitu hidayah Allah SWT hadir dalam hati sang ayah. Tentunya, dalam melakukan hal tersebut Nabi Ibrahim 'alaihi salam tidak bebas dari tantangan, salah satunya beliau pernah dihukum dengan dibakar hidup-hidup oleh raja kala itu. Pertolongan Allah SWT menyelamatkannya dan mengantarkannya menjadi sosok yang kelak rumah ibadah yang dibangunnya digunakan oleh jutaan umat manusia dari masa ke masa hingga hari kiamat.

Berdasarkan pemaparan di atas, motivasi berprestasi pada siswa SMA dapat tumbuh seiring dengan meningkatnya keimanan dan ketakwaannya. Niat dan tujuan yang bermakna akan menuntunnya dan membangkitkan motivasi berprestasi dalam dirinya. Motivasi seorang siswa SMA yang tinggi akan menuntunnya mencapai prestasi. Sementara, pada saat yang sama dengan niat untuk menggapai ridha Allah SWT maka segala upaya yang dilakukan untuk mencapai prestasi akan bernilai ibadah. Hal ini justru akan mempertebal keimanan dan berakibat pada meningkatnya motivasi internal individu siswa SMA tersebut. Dengan demikian, semakin tinggi keimanan dan ketakwaan seorang siswa SMA maka semakin tinggi pula motivasi berprestasi yang dimilikinya. Tingginya motivasi berprestasi akan mendukung tercapainya prestasi yang tinggi pula. Harapannya, hal ini pun akan berdampak positif pada peningkatan kualitas sumber daya manusia.

\section{Simpulan}

Motivasi berprestasi adalah usaha individu yang dilakukan dengan tekun untuk menggapai keberhasilan yang dipicu oleh interaksi dirinya dengan orang lain atau lingkungannya sehingga kebutuhannya terpenuhi. Motivasi berprestasi penting untuk dipelihara dan senantiasa ditingkatkan, terlebih pada siswa SMA. Hal ini dikarenakan siswa SMA adalah kaum remaja sekaligus sebagai generasi penerus yang menyimpan banyak potensi yang pada gilirannya akan menjadi unsur peubah bangsa di masa depan dan mampu memberi dorongan untuk meraih keberhasilan dalam akademik, baik berupa kompetensi, keterampilan, atau suatu prestasi yang membanggakan. Hal ini akan secara otomatis meningkatkan kualitas sumber daya manusia Indonesia. Sementara dalam perspektif Islam, motivasi berprestasi merupakan dorongan untuk mencapai suatu hasil yang disertai niat untuk menggapai ridha Allah SWT dan atas upaya yang dilakukan akan dinilai sebagai ibadah. Sementara itu, penganut agama Islam akan memiliki motivasi yang besar seiring dengan meningkatnya keimanan dan ketakwaannya terhadap Allah.

Hasil dari studi literatur ini adalah untuk memberikan informasi tentang tantangan dan sekaligus peluang penelitian yang difokuskan pada motivasi berprestasi pada kalangan siswa menengah atas yang jumlahnya masih terbatas. Hasil penelitian ini menghasilkan informasi minimum mengenai motivasi berprestasi pada siswa SMA dalam perspektif Islam. Sebagai bagian dari proses yang mendukung peningkatan kualitas sumber daya manusia Indonesia pada usia produktif, motivasi berprestasi siswa SMA memiliki peran penting dalam 
mengkonsolidasi pencapaian prestasi belajar sekaligus persiapan estafeta kepemimpinan bangsa secara tidak langsung. Hasil penelitian ini diharapkan dapat membantu pihak selanjutnya untuk melakukan studi yang lebih mendalam tentang motivasi berprestasi di kalangan siswa SMA.

Penelitian ini dilakukan melalui pencarian online pada literatur pada sejumlah database jurnal elektronik menggunakan kata kunci dengan topik yang telah ditentukan. Ada basis data lain yang barangkali memuat artikel jurnal tentang motivasi berprestasi dalam perspektif Islam yang belum terungkap dalam penelitian ini. Selain itu, ada faktor-faktor yang belum dipelajari tentang motivasi berprestasi, seperti motivasi berprestasi di kalangan siswa sekolah dasar atau di bawahnya dalam perspektif Islam. Peneliti selanjutnya juga diharapkan dapat melakukan penelitian dan menganalisis pengaruh motivasi berprestasi dalam perspektif agama selain Islam.

\section{DAFTAR PUSTAKA}

Al-Asqalany, I. H. (1998). Fathul bari fi shahih AL Bukhary, Juz I. Kairo: Dar el Hadits. al-Husein, A. (1918). Shahih muslim. Kairo: Dar al-Kutub.

Al-Mighwar, M. (2011). Psikologi remaja. Bandung: Pustaka Setia.

Awan, R. U., Noureen, G., \& Naz, A. (2011). A study of relationship between achievement motivation, self concept and achievement in english and mathematics at secondary level. International Journal Education Studies, 4(3), 1913-9020.

Baharuddin. (2004). Paradigma psikologi Islami. Yogyakarta: Pustaka Pelajar.

Cramer, K. M., Lafreniere, K. D., Ianni, P. A., \& Lafreniere, K. D. (2015). Scholarship at Uwindsor respondent self-focus and the internal consistency of the motivational style profile respondent self-focus and the internal consistency of the motivational style profile. Journal of Motivation, Emotion, and Personality, 4(4), 26-32.

Depag. (1992). Al-Qur'an dan terjemahnya (Departemen Agama). Semarang: PT Tanjung Mas Inti.

Djamarah, S. B. (2010). Guru dan anak didik dalam interaksi edukatif. Jakarta: Rineka Cipta.

El-Fiky, I. (2011). 10 Keys to ultimate sucsses,Terj. Bagus Dewanto. Jakarta: Tugu Publisher.

Fakhria, M., \& Setiowati, E. A. (2017). Motivasi berprestasi siswa ditinjau dari fasilitasi sosial dan ketakutan akan kegagalan. Psikohumaniora: Jurnal Penelitian Psikologi, 2(1), 29-42.

Gage, N., \& Berliner, D. (1984). Educational psychology. Boston: Houghton Mifflin Co.

Hakim, M. S. (2016, Maret 19). Akhlak dan nasihat. Retrieved from Muslim.or.id: https://muslim.or.id/27701-nasihat-dan-bimbingan-untuk-pemuda-muslim-terhadapdiri-agama-dan-masyarakatnya.html.

Hall, C., \& Lindsey, G. (1985). Introduction to theories of personality. New York: Jhon Wiley and Sons.

Haryani, R., \& Tairas, M. M. (2014). Motivasi berprestasi pada mahasiswa berprestasi dari keluarga tidak mampu secara ekonomi. Jurnal Psikologi Pendidikan dan Perkembangan (Vol. 3), 30-36.

Hassan, S. N., \& Abdullah, B. (2018). Importance of duty of worship and qudwah hasanah in the developmental process of adolescent baligh. International Social Science and Humanities Journal, 1(2), 1-10.

Hendrati, F. (2014). Hubungan motivasi berprestasi dan harga diri dengan kinerja guru SD di Malang masyarakat Indonesia mempunyai harapan Sebaik-baiknya. Jurnal Psikologi Tabularasa, vol. 9, 151-160.

Howard, R. (2016). Is motivational style related to sex or gender identity? a study of young singaporeans, vol. 5, 18-26.

Izzanuddin, T. M. (2006). Psikologi Islam. Jakarta: Gema Insani.

Jannah, M. (2016). Remaja dan tugas-tugas perkembangannya dalam Islam. Jurnal Psikoislamedia, 1(1), 243-255. 
Kartika, A. (2017). Fenomena kenakalan remaja dalam perspektif psikologi pendidikan Islam. G-COUNS Jurnal Bimbingan dan Konseling, 2(1), 59-73.

Kemendikbud RI. (2013). Permendikbud nomor 69 tahun 2013 tentang kerangka dasar dan struktur kurikulum sekolah menengah atas/madrasah aliyah. Jakarta: Penulis.

Kemendikbud RI. (2018). Permendikbud RI Nomor 36 Tahun 2018 perubahan atas peraturan menteri pendidikan dan kebudayaan nomor 59 tahun 2014 tentang kurikulum 2013 Sekolah Menengah Atas/Madrasah Aliyah. Jakarta: Penulis.

Kemendikbud RI, Puspendik. (2019, April 20). Capaian nasional. Retrieved from Pusat Penilaian Pendidikan, Kementerian Pendidikan dan Kebudayaan: https://hasilun. puspendik.kemdikbud.go.id.

Kemendikbud. (2019, Januari 16). Kamus besar bahasa Indonesia (KBBI). Retrieved from KBBI Daring: http://kbbi.kemdikbud.go.id.

McClelland, D. (1987). Human motivation. Cambridge: Cambridge University Press.

Poledňová, I., Stránská, Z., \& Niedobová, H. (2014). Achievement motivation of secondary school students in relation to their social position in the class. Problems Of Psychology In The 21st Century, 8(1), 61-70.

Salim, S., \& Salim, Y. (1991). Kamus Besar Bahasa Indonesia Kontemporer. Jakarta: Modern Press.

Santrock, J. W. (2011). Educational psychology 5th edition. Texas: Mc.Graw Hill.

Sapuri, R. (2009). Psikologi Islam: Tuntunan jiwa manusia modern. Jakarta: PT Rajagrafindo Persada.

Savitri, N. P., Santyasa, I. W., \& Rapi, N. K. (2017). Analisis kualitatif strategi pembelajaran guru fisika: Relevansinya dalam pengembangan motivasi berprestasi dan self-efficacy siswa. Wahana Matematika dan Sains: Jurnal Matematika, Sains, dan Pembelajarannya, 11(2), 107-124.

Singh. (2011). Study of achievement motivation in relation to academic achievement of student. International Journal of Educational Planning \& Administration, 1(2), 161-171.

Suranto. (2015). Pengaruh motivasi, suasana lingkungan dan sarana prasarana belajar terhadap prestasi belajar siswa (studi kasus pada SMA khusus putri SMA Islam Diponegoro Surakarta). Jurnal Pendidikan Ilmu Sosial, vol. 25, 11-19.

Tucker, C. M., Zayco, R. A., \& Herman, K. C. (2002). Teacher and child variables as predictors of academic engagement among. Journal Psychology in the Schools, 39(4), 477-488.

Utomo, P., Atmoko, A., \& Hitipeuw, I. (2018). Peningkatan motivasi berprestasi siswa SMA melalui cognitive behavior counseling teknik self-instruction dan self-monitoring. Jurnal Pendidikan: Teori, Penelitian, dan Pengembangan, 3(4), 416-423. 